\title{
Physics Teacher's Misconceptions About Direct Current Material
}

\author{
Afifah Yuliani Adhim¹, Budi Jatmiko², Tjipto Prastowo ${ }^{3}$ \\ 1,2,3 Universitas Negeri Surabaya, Surabaya, Indonesia
}

\begin{tabular}{|c|c|}
\hline (A) Check for updates open $\partial$ access (c) $\underset{\mathrm{EY}}{\mathrm{SP}}$ & DOI : https://doi.org/10.46245/ijorer.v2i6.160 \\
\hline Sections Info & ABSTRACT \\
\hline Article history: & The teacher's conception is one of the misconceptions that students encounter, \\
\hline Submitted: September 8, 2021 & so it is critical to uncover the status of the teacher's conception to improve the \\
\hline Final Revised: October 19, 2021 & students' conception. The purpose of this research is to identify physics \\
\hline Accepted: November 11, 2021 & teachers' misconceptions about direct current material. There were 16 Physics \\
\hline Published: November 30, 2021 & Teachers in one of the districts in East Java, including 7 (seven) teachers from \\
\hline Keywords: & the Public High School (Negeri) and 9 (nine) teachers from private schools \\
\hline Direct Current & (Swasta). This research is quantitative descriptive analysis research. A three- \\
\hline Misconception & tier diagnostic test was used to analyze the data, revealing that teachers' \\
\hline Three-tier test & $\begin{array}{l}\text { average percentage of misconceptions was } 58 \% \text { in a medium category. The } \\
\text { results also showed that physics teachers had the highest rate of }\end{array}$ \\
\hline 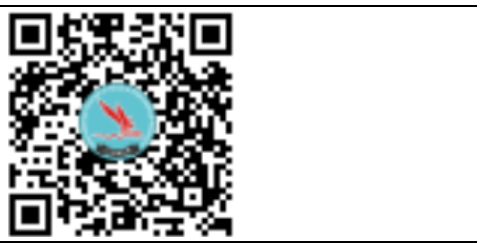 & $\begin{array}{l}\text { misconceptions in the Potential Difference sub-concepts }(94 \%) \text {, while the } \\
\text { Series Circuit concept had the lowest proportion of misconceptions }(25,50 \%) \text {. } \\
\text { Misconceptions experienced by physics teachers must be addressed } \\
\text { immediately because they will impact students conceptions. The results of } \\
\text { this study are very important for policy makers, especially the Education } \\
\text { Office to find solutions in breaking the chain of physics misconceptions. }\end{array}$ \\
\hline
\end{tabular}

\section{INTRODUCTION}

Students will develop their knowledge while interacting with the environment; this knowledge is a naive concept or preconception. Students will assimilate their initial thought with new knowledge after completing the learning processes. However, students' original concepts are frequently different from the concepts taught by their teachers, resulting in misconceptions. Beliefs that contradict well-accepted scientific theories are called misconceptions (Kuczmann, 2017).

Misconceptions exist in the natural sciences, including all physics concepts (Suprapto, 2020). The concept of direct electric current is one of the many physics topics that is widely misunderstood. Misconceptions regarding direct electric current are second only to those concerning mechanics (Zulvita, 2017). It is because the direct current is an abstract concept. Many students and prospective physics teachers struggle to grasp the concept of electricity (Yunita, 2017).

Among the many misconceptions about direct current material are: In the Direct Current concept, the current flowing steadily declines as the resistance consumes it goes through (Ergin and Atasoy, 2013). The further the light is from the power supply (battery) in the concept of a series electrical circuit, the dimmer the bulb will be (Halim, 2019). The current is divided equally at each branch in the concept of a parallel electric circuit, with no consideration for the value of each resistance (Urban, 2017)

Students might get the main sources of misconceptions from personal experience, textbooks, the language used, and the teacher (Herman, 2016). Teachers have a significant influence on the rate of students' misconceptions. There is significant evidence that teachers are the main source of student misconceptions (Kaltakci-Gurel et al., 2016). A teacher who does not master or understand a concept incorrectly will cause 
students to have misconceptions (Suprapto, 2020). Misconceptions experienced by teachers impact the construction of students' conceptions; consequently, it is vital to identify the state of teachers' misconceptions to enhance students' conceptions.

According to a study conducted at one of Bangkalan's high schools, student misconceptions about direct current material are still significant, ranging from $52 \%$ to $86 \%$. Based on these findings, the purpose of this study is to describe the percentage of physics teachers, the misconceptions of physics teachers in the sub-concept of direct current, and indeed the misconceptions of physics teachers on the direct current material. As a result, it is necessary to determine the teachers' conception; if required, a modification can be performed to improve the students' conception (Kaltakci-Gurel et al., 2016). In this context, identifying teachers' misconceptions about various concepts of direct current becomes an essential item to investigate.

A three-tier test is one technique for identifying students' misconceptions. A threetier diagnostic test is a tool used to identify students' misconceptions about a particular concept. The three-tier test combines the two-tier test and the Certainty Response Index (CRI) (Hasyim et al., 2018); moreover, it was developed by Eryilmaz and Surneli. The three-tier test instrument has the advantage of differentiating between conceptions and students who do not comprehend or do not know concepts based on the students' beliefs from their replies (Kamilah and Suwarna, 2016); thus, it will be accurate in detecting misconceptions.

The three-tier test is divided into three stages: (1) the first level asks descriptive questions, (2) the second level asks reasons for the answers, which are also attached by options in the form of an empty essay (free response) to determine whether the students experience new misconceptions or not and the misconception outside previous literature, and (3) the third level asks the students' beliefs in answering the items (Jusniar et al., 2020). The purpose of this research is to identify physics teachers' misconceptions about direct current material.

\section{RESEARCH METHOD}

This study used quantitative descriptive analysis to identify the misconception profile of physics teachers in one of the districts in East Java, particularly for direct current material. The data were examined using a three-tier diagnostic procedure that three experts validated. The results showed that the Three-tier Diagnostic Test Instrument that would be used had a very valid category and was reliable. The diagnostic test data were then evaluated, and the percentage result obtained for average validity was 92,4 $\%$, and reliability was $88,1 \%$.

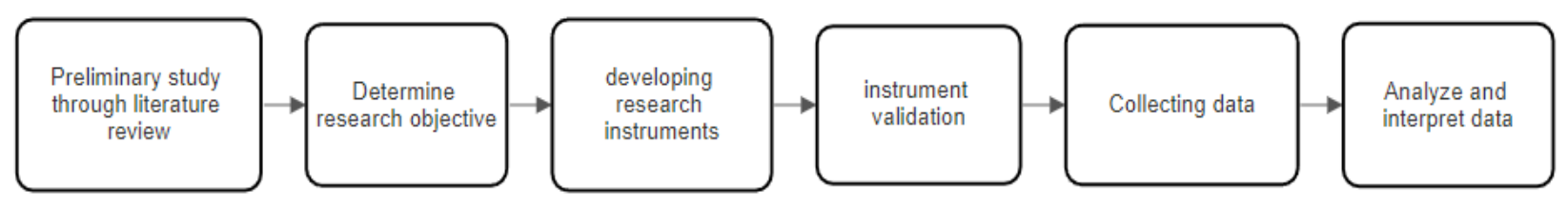

Figure 1. Flowchart of research procedure.

The subjects of this study were 16 physics teachers from one of the districts in East Java, including seven from Public High Schools (Negeri) and nine from Private High Schools (Swasta). The three-tier diagnostic test of misconception was used in this study to identify the misconception profile of physics teachers in direct current material. The 
test comprised 15 true and false reasons and level of belief questions that the study subject had to answer.

To analyze the percentages of misconceptions for each physics teacher, the following equation (1) could be used:

Description:

$$
M=\frac{a}{n} \times 100 \%
$$

$M=$ the percentage of misconceptions of each physics teacher

$\mathrm{A}=$ number of answers of physics teachers which categorized as misconceptions

$\mathrm{N}=$ total number of questions

To compute the percentage of misconceptions for each direct current sub-concept, the following equation (2) could be used:

Description:

$$
P=\frac{J}{N} \times 100 \%
$$

$\mathrm{P}=$ The answer percentage of physics teachers in the category of misconceptions on each direct-current electric concept.

$\mathrm{J}=$ The number of physics teachers' answers categorized as misconceptions on each direct electric current concept.

$\mathrm{N}=$ Number of physics teachers who attended the test.

Furthermore, the following Table 1 could be used to determine the level of misconception among physics teachers about direct current material (Widiarini, 2020):

Table 1. Misconception level.

\begin{tabular}{cc}
\hline Percentages & Categories \\
\hline 0 to $30 \%$ & Low \\
$31 \%$ to $60 \%$ & Medium \\
$61 \%$ to $100 \%$ & High \\
\hline
\end{tabular}

\section{RESULTS AND DISCUSSION}

This study aims to identify physics teachers' misconceptions about direct current material using three-tier diagnostic tests. Figure 2 illustrates the percentages of physics teachers who have misconceptions.

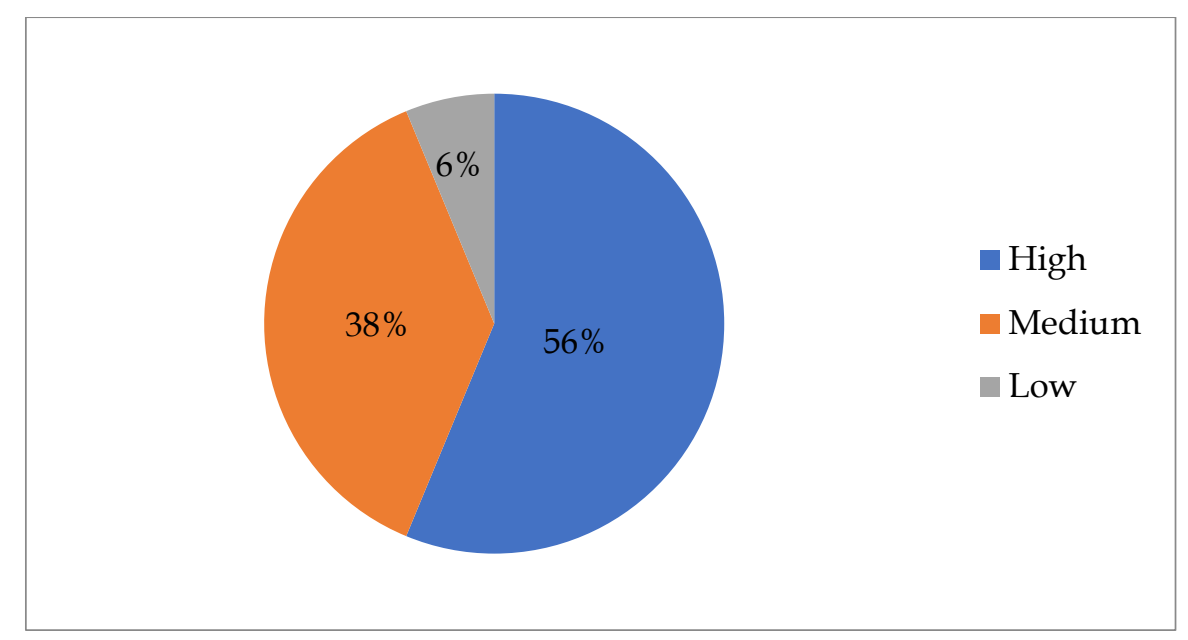

Figure 2. Misconception of physics teachers regarding direct current material. 
According to Figure 2, 6\% of physics teachers had low-level misconceptions, 38\% had medium-level misconceptions, and $56 \%$ had high-level misconceptions. In a medium category, the average percentage of misconceptions encountered by physics teachers was $58 \%$. It is consistent with a study conducted by Suryadi et al. (2020), which found that the misconception percentage of direct current material for Middle School students is $62,78 \%, 61,72 \%$ for High School students $45,56 \%$ for prospective physics teachers. The average percentage of misconception experienced by physics teachers in direct current material implies that physics teachers' conceptual competence in direct current material is still low. Misconceptions can affect anyone, including adults, teachers, and even professors (Suprapto, 2020). Misconceptions experienced by teachers will impact students' conceptual mastery, as teachers are the student's primary learning sources. According to the study's findings, students or teacher candidates who have misconceptions about electricity will find it challenging to construct simple electrical circuits (Onder et al., 2017).

The Three-tier test was utilized in this study to discover physics teachers' misconceptions about direct current material, which included various sub-concepts such as electric current, electrical resistance, potential difference, Ohm's law, resistance circuit, and Kirchoff's law. Figure 3 depicts the percentages of physics teachers who misunderstand each sub-concept of direct current.

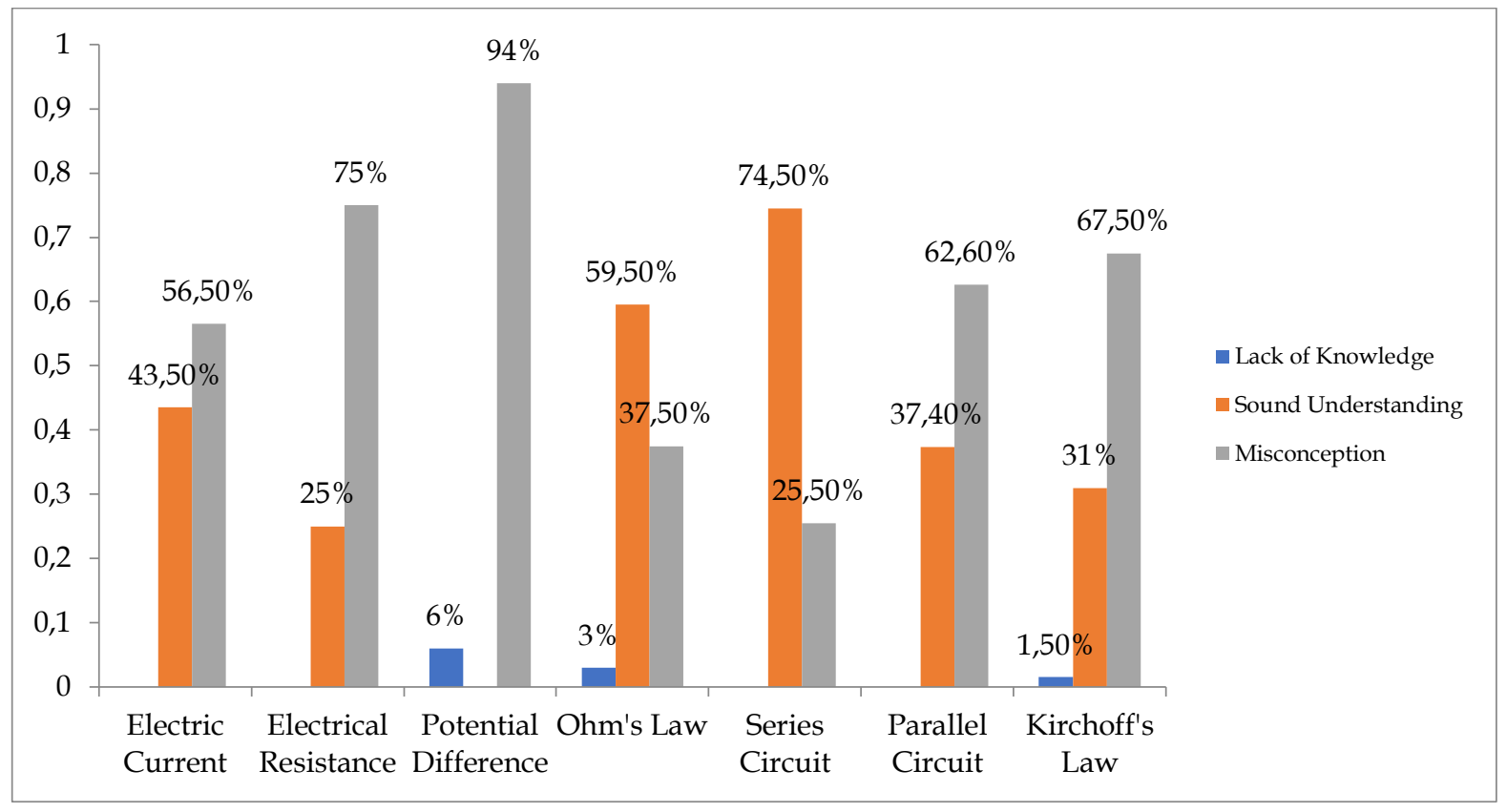

Figure 3. Misconception of physics teachers regarding the sub-concept of direct current.

According to Figure 3, the physics teacher had the most prominent misconception in the potential difference sub-concept, $94 \%$, and the lowest misconception in the series circuit concept, $25,50 \%$. It is consistent with the findings of a study done by Kurniawan and Maryanti (2018), which reveals that prospective teachers experience misconceptions in the potential difference sub-concept for above 5\%. According to Samsudin et al. (2019), from 27 subjects, 20 people experience misconceptions regarding the potential difference sub-concept. $20 \%$ of the total subjects of study experience misconceptions on the sub-concepts of series and parallel resistance circuits. Figure 3 also revealed that 
physics teachers had misconceptions in the entire sub-concept of direct current with a medium to the high category. It includes $56,50 \%$ on electric current concepts, $75 \%$ on electrical resistance, $94 \%$ on potential difference concepts, $37,50 \%$ on Ohm's law concepts, $25,50 \%$ on series circuit concepts, and $62,60 \%$ on parallel circuit concepts, and $67,50 \%$ on the Kirchoff's law.

\section{Misconception Description of Physics Teachers on Direct Current Material}

The results of the three-tier diagnostic test analysis revealed that $94 \%$ of physics teachers had misconceptions about the potential difference sub-concepts. They assumed that the potential difference was caused by the current, so that if there was no current, there was no voltage, despite the fact that the potential difference was the amount of electrons present in an electric current. The teachers assumed that if the current was zero in an open circuit, the voltage was also zero.

$75 \%$ of physics teachers had misconceptions about electrical sub-concepts. They assumed that when the switch was opened, the resistance was zero. According to physics concepts, voltage, and current affect resistance, whereas length, cross-sectional area, and material type influence resistance size. A wire's resistance is related to its length $L$ and inversely proportional to its cross-sectional area $A$ (Giancoli, 2014)

There were $67,5 \%$ of physics teachers who had misconceptions about Kirchoff's law. They thought that when a branch formed, more current flowed through it in the direction of the main branch than through the bent branch. According to physics, the current that flows through a branching point in an electric circuit equals the current that flows out of the branching point (Aisahsari and Ermawati, 2020). 62,60\% of physics teachers experienced misconceptions about parallel circuit resistance. They thought that in the parallel circuit, the current was divided equally at the first and second branches. The students were unable to determine whether the bulbs were identical or not. If the bulbs were similar, the resistance of each bulb would be equal. In contrast, in a parallel circuit, the potential difference in each branch is the same. Therefore if the resistance is the same, the current flowing in each branch is likewise the same. They also assumed that the more resistors added in parallel, the greater the total resistance, whereas when the resistors were connected in parallel, the potential difference across the resistors was the same. It is in line with a study conducted by Widodo et al. (2018) that from 30 science teachers, only $17 \%$ of teachers have correct concepts about the parallel circuits, while the rest of it experiences misconceptions.

There were $59,50 \%$ of physics teachers who experienced misconceptions in Ohm's law. They considered that the bulb's brightness was affected by resistance before passing through the bulb; other obstacles after the bulb did not affect the bulb's brightness even though the bulb's brightness in the circuit was affected by the total resistance in the circuit. The concept of direct current was misunderstood by $56,50 \%$ of physics teachers. They assumed that for the current to flow (light to turn on), just one battery pole (positive or negative) was connected to the lamp. According to physics, if the positive and negative poles of a battery are connected to a lamp, the lamp will light up (Aisahsari and Ermawati, 2020). It implies that a direct electrical current travels from the battery to the bulb when the circuit is linked. According to Kurniawan and Maryanti (2018), 81\% of prospective teachers have misconceptions about direct current sub-concepts. $50 \%$ of physics teachers had misconceptions about series resistance subconcepts. The teachers assumed that current would decrease as it passed through a circuit; the other the light bulb was from the power source, the dimmer the lamp would 
be, even though the current flowing through each resistance in a series circuit was the same. It is in line with a study conducted by Hesti et al. (2017), who reveals that the student claims that the electric current will be consumed by the lamp that passes first.

\section{CONCLUSIONS}

Based on the findings, analysis, and discussion, it is known the average percentage of misconceptions experienced by physics teachers in the medium category. The potential difference sub-concept has the largest number of misconceptions in the direct current electric sub-concept, while the series circuit concept has the lowest percentage of misconceptions. Physics teachers misunderstand all sub-concepts of direct electric current with medium to high categories. Misconceptions experienced by physics teachers must be addressed immediately because they will impact students' conceptions. The results of this study are significant for policymakers, especially the Education Office, to find solutions in breaking the chain of physics misconceptions. Future research can be done on another students of senior and junior high school.

\section{REFERENCES}

Aisahsari, R., \& Ermawati, M.U. (2020). Evaluating student's misconceptions and the causes on direct current concept by means of four-tier multiple choice test. Journal of Physics: Conference Series, 1491(1), 1-9. https://doi.org/10.1088/1742-6596/1491/1/012009

Ergin, S., \& Atasoy, S. (2013). Comparative analysis of the effectiveness of 4 mat teaching method in removing pupils' physics misconceptions of electricity. Journal of Baltic Science Education, 12(6), 730-746.

Herman. (2016). Factors contributing ti students' misconceptions in learning covalent bonds. Journal Of Research in Science Teaching, 54(4), 520-537. https://doi.org/10.1002/tea.21375

Giancoli, D. C. (2014). Physics principles with applications seventh edition. United States of America: Pearson Education.

Kaltakci-Gurel, D., Eryılmaz, A., \& McDermott, L.C. (2016). Identifying pre-service physics teachers' misconceptions and conceptual difficulties about geometrical optics. European Journal of Physics, 37(4), 1-31. https://doi.org/10.1088/0143-0807/37/4/045705

Halim, A, Lestari D., \& Mustafa. (2019). Identification of the causes of misconception on the concept of dynamic electricity. Journal of Physics: Conference Series, 1280(5), 1-7. https://doi.org/10.1088/1742-6596/1280/5/052060

Hasyim, W., Suwono, H., \& Susilo, H. (2018). Three-tier test to identify students' misconception of human reproduction system. Jurnal Pendidikan Sains, 6(2), 48-54.

Hesti, R., Maknun, J., \& Feranie, S. (2017). Text based analogy in overcoming student misconception on simple electricity circuit material. International Conference on Mathematics and Science Education (ICMScE), 895(1), 1-11. https://doi.org/10.1088/17426596/895/1/012146

Jusniar, J., Effendy, E., Budiasih, E., \& Sutrisno, S. (2020). Developing a three-tier diagnostic instrument on chemical equilibrium (TT-DICE). Educación Química, 31(3), 84-102. https://doi.org/10.22201/fq.18708404e.2020.3.72133

Gurel, D.K., \& Körhasan, N. D. (2007). Identification of pre-service physics teachers' misconceptions on gravity concept: A study with a 3-tier misconception test. AIP Conference Proceedings, 899(1), 499-500. https://doi.org/10.1063/1.2733255

Kamilah, D. S., \& Suwarna, I. P. (2016). Pengembangan three-tier test digital untuk mengidentifikasi miskonsepsi pada konsep fluida statis. Edusains, 8(2), 212-220. https:/ / doi.org/10.15408/es.v8i2.5192

Kuczmann, I. (2017). The structure of knowledge and students' misconseptions in physics. AIP Conference Proceedings, 1916(1), 1-7. https:// doi.org/10.1063/1.5017454. 
Kurniawan, D. T., \& Maryanti, S. (2018). Analysis of math teacher candidates' misconceptions on the dynamic electricity concept. Scientiae Educatia: Jurnal Pendidikan Sains, 7(1), 67-78. https:// doi.org/10.24235/sc.educatia.v7i1.2481

Onder, F., Senyigit, S., \& Silay, I. (2017). The effect of misconceptions on pre-service teacher's ability to constructing simple electric circuits. Europan Journal of Physics Education, 8(1), 1309-7202.

Samsudin, A., Azura, Kaniawati, I., Suhandi, A., Fratiwi, N. J., Supriyatman, Wibowo, F. C., Malik, A., \& Coştu, B. (2019). Unveiling students' misconceptions through computer simulation-based PDEODE learning strategy on dynamic electricity. Journal of Physics Conference Series, 1280(4), 1-10. https:/ / doi.org/10.1088/1742-6596/1280/5/052050

Suprapto, N. (2020). Do we experience misconceptions?: An ontological review of misconceptions in science. Studies in Philosophy of Science and Education, 1(2), 50-55. https://doi.org/10.46627/sipose.v1i2.24

Suryadi, A., Kusairi, S., \& Husna, D. A. (2020). Comparative study of secondary school students' and pre-service teachers' misconception about simple electric circuit. Jurnal Pendidikan Fisika Indonesia, 16(2), 111-121. https:/ / doi.org/10.15294/jpfi.v16i2.21909

Urban, H. (2017). Sequential reasoning in electricity: Developing and using a three-tier multiple choice test. Scientia in Educatione, 8(1), 285-292. https:// doi.org/10.14712/18047106.755.

Widiarini, P. (2020). Profil miskonsepsi mahasiswa calon guru fisika pada konsep gaya. Wahana Matematika dan Sains: Jurnal Matematika, Sains, dan Pembelajarannya, 14(1), 203-214. https:// doi.org/10.23887/wms.v14i1.24265

Widodo, W., Rosdiana, L., Fauziah, A.M., \& Suryanti. (2018). Revealing student's multiplemisconception on electric circuit. Journal of Physics: Conferences Series, 1108(1), 1-11. https://doi.org/10.1088/1742-6596/1108/1/012088

Yunita. (2017). Identifikasi miskonsepsi mahasiswa calon guru fisika pada pokok bahasan rangkaian listrik melalui certainly of response index. Prosiding Seminar Nasional Pascasarjana (SNP) Unsyiah, 2017(1), 94-102.

Zulvita, R., Halim, A., \& Elisa. (2017). Identifikasi dan remediasi miskonsepsi konsep hukum newton dengan menggunakan metode eksperimen di MAN Darussalam. JIMPF: Jurnal Ilmiah Mahasiwa Pendidikan Fisika, 2(1), 128-134.

\footnotetext{
*Afifah Yuliani Adhim, S,Pd. (Corresponding Author)

Postgraduate Program, Science Education

Universitas Negeri Surabaya

Jl. Lidah Wetan, Surabaya, East Java, Indonesia

Email: Afifah.19008@mhs.unesa.ac.id
}

Prof. Dr. Budi Jatmiko, M.Pd.

Postgraduate Program, Science Education

Universitas Negeri Surabaya

Jl. Lidah Wetan, Surabaya, East Java, Indonesia

Email: budijatmiko@unesa.ac.id

Prof. Tjipto Prastowo, Ph.D.

Postgraduate Program, Science Education

Universitas Negeri Surabaya

Jl. Lidah Wetan, Surabaya, East Java, Indonesia

Email: prastowo.tjipto@gmail.com 